\title{
Variations in the Sporulation Efficiency of Pathogenic Freshwater Oomycetes in Relation to the Physico-Chemical Properties of Natural Waters
}

\author{
Dora Pavić, Dorotea Grbin, Marija Gregov (D), Josip Ćurko (D), Tomislav Vladušić, Lidija Šver, Anđela Miljanović \\ and Ana Bielen *(i)
}

check for updates

Citation: Pavić, D.; Grbin, D.; Gregov, M.; Ćurko, J.; Vladušić, T.; Šver, L.; Miljanović, A.; Bielen, A. Variations in the Sporulation Efficiency of Pathogenic Freshwater Oomycetes in Relation to the Physico-Chemical Properties of Natural Waters. Microorganisms 2022, 10, 520. https://doi.org/10.3390/ microorganisms 10030520

Academic Editor: Matthias Labrenz

Received: 28 January 2022

Accepted: 25 February 2022

Published: 27 February 2022

Publisher's Note: MDPI stays neutral with regard to jurisdictional claims in published maps and institutional affiliations.

Copyright: (c) 2022 by the authors. Licensee MDPI, Basel, Switzerland. This article is an open access article distributed under the terms and conditions of the Creative Commons Attribution (CC BY) license (https:// creativecommons.org/licenses/by/ $4.0 /)$.
Faculty of Food Technology and Biotechnology, University of Zagreb, Pierottijeva 6, 10000 Zagreb, Croatia; dpavic@pbf.hr (D.P.); dorotea.polo@gmail.com (D.G.); marija.gregov@pbf.unizg.hr (M.G.); jcurko@pbf.hr (J.Ć.); tvladusic@pbf.hr (T.V.); lsver@pbf.hr (L.Š.); amiljanovic@pbf.hr (A.M.)

* Correspondence: abielen@pbf.hr; Tel.: +385-1-4836-013

\begin{abstract}
Oomycete pathogens in freshwaters, such as Saprolegnia parasitica and Aphanomyces astaci, are responsible for fish/crayfish population declines in the wild and disease outbreaks in aquaculture. Although the formation of infectious zoospores in the laboratory can be triggered by washing their mycelium with natural water samples, the physico-chemical properties of the water that might promote sporulation are still unexplored. We washed the mycelia of A. astaci and S. parasitica with a range of natural water samples and observed differences in sporulation efficiency. The results of Partial Least Squares Regression (PLS-R) multivariate analysis showed that SAC (spectral absorption coefficient measured at $254 \mathrm{~nm}$ ), DOC (dissolved organic carbon), ammonium-N and fluoride had the strongest positive effect on sporulation of $S$. parasitica, while sporulation of $A$. astaci was not significantly correlated with any of the analyzed parameters. In agreement with this, the addition of environmentally relevant concentrations of humic acid, an important contributor to SAC and DOC, to the water induced sporulation of S. parasitica but not of $A$. astaci. Overall, our results point to the differences in ecological requirements of these pathogens, but also present a starting point for optimizing laboratory protocols for the induction of sporulation.
\end{abstract}

Keywords: Aphanomyces astaci; crayfish plague; dissolved organic carbon (DOC); humic acid (HA); Saprolegnia parasitica; saprolegniosis; spectral absorption coefficient (SAC); zoospores

\section{Introduction}

Animal pathogenic oomycetes are a cause of serious diseases worldwide [1-3], and in freshwater ecosystems species from the genera Aphanomyces and Saprolegnia are the most significant, since they cause severe disease outbreaks both in aquaculture and in the wild [4-7]. Crayfish plague, a disease caused by Aphanomyces astaci is responsible for decimating the populations of indigenous crayfish species in Europe [8] and elsewhere (e.g., Asia and South America) [9-12]. The pathogen was introduced into Europe along with North American non-indigenous invasive crayfish species which now act as its carriers, being mostly resistant to infection due to a long co-evolution with the pathogen $[13,14]$. Members of the genus Saprolegnia cause saprolegniosis, which is responsible for significant economic losses in salmonid farms and hatcheries [15-18]. Among them, Saprolegnia parasitica is highly virulent and widespread $[4,7,19,20]$, and recent studies suggest that aquaculture facilities can act as the sources of its spread into the natural environment $[21,22]$.

The complete life cycle of oomycetes involves asexual and sexual stages, although in some species, including $A$. astaci, the sexual stage has not been documented $[6,23,24]$. The asexual stage is considered crucial for pathogen's dispersal, since it includes the production of motile zoospores, the major infectious stage of the life cycle $[23,24]$. Zoospores are released into the surrounding water from the hyphal tips (i.e., sporangia) after colonizing 
the infected host tissue $[23,25]$, and the new infection is established when they locate the suitable host by chemotaxis [26,27]. Zoospores encyst on the surface of the host, such as on the crayfish cuticle or fish skin, and then germinate into hyphae that penetrate the body of the host [6,28-30]. In some oomycete species, including A. astaci and S. parasitica, if zoospores are unable to find a suitable host, they encyst and then release a new zoospore generation (repeated zoospore emergence), thereby increasing the possibility of finding a suitable host [31,32]. Dispersal of zoospores from one host to another by water and by contaminated items (like fishing gear) present the main way of spreading the oomycete diseases in freshwater systems [25,33,34].

The formation of zoospores can be triggered under laboratory conditions, for example, by the lack of nutrients or after a sudden drop in temperature $[28,35,36]$. Most protocols for sporulation of oomycetes are therefore based on washing the mycelium with stream or lake water, but without defining the components present in the water $[32,37,38]$. During our work with $A$. astaci and S. parasitica, we noticed that sporulation efficiency varied depending on the water used to wash the mycelium. This suggested that the water composition might influence the sporulation process, but there is little data on this in the literature. Several in vitro studies have shown that some salts, such as $\mathrm{KCl}, \mathrm{NaCl}, \mathrm{MgCl}_{2}, \mathrm{CaCl}_{2}$ or $\mathrm{K}_{2} \mathrm{SO}_{4}$, can affect the formation, motility and germination of oomycete zoospores $[31,39,40]$, but the salt concentrations used were significantly higher than in natural freshwaters [41]. However, a recent study used environmentally relevant concentrations of a sea salt mixture ranging from 0 to $45 \mathrm{~g} / \mathrm{L}$ and found that survival, growth and infectivity of the plant oomycete pathogen Phytophthora ramorum were negatively correlated with salt concentration [42]. At concentrations $>20 \mathrm{~g} / \mathrm{L}$, no zoospores were released, but infection could still occur via mycelial growth.

We hypothesized that physico-chemical characteristics of natural waters can affect the intensity of sporulation of freshwater pathogenic oomycetes, and the aim of this study was to test for the first time the sporulation efficiency of two oomycete pathogens, A. astaci and S. parasitica, upon washing their mycelia with natural surface waters of varying physicochemical characteristics. The subsequent statistical analysis allowed us to identify the specific parameters of natural waters that could stimulate or inhibit the zoospore formation in freshwater oomycetes.

\section{Materials and Methods}

\subsection{Water Sampling}

Water sampling was performed during winter 2018/2019 in different freshwater bodies in Croatia (Figure 1, Table S1). Water sampling locations $(n=36)$ were selected to vary in terms of geological composition of the substrate, ecosystem type (lentic or lotic) and ecoregion (Dinaric with continental or Mediterranean climate, or Pannonic with continental climate) (Table S1). For some of the locations, data on the presence/absence of the model pathogens A. astaci and S. parasitica were also available. Water was sampled into autoclaved $1 \mathrm{~L}$ polyethylene bottles previously washed three times with the sample and kept in the dark and on ice during transport. Upon arrival to the laboratory, the water samples were immediately autoclaved and then placed in a dark room at $+18{ }^{\circ} \mathrm{C}$ until physico-chemical analyses (see Section 2.2) and sporulation experiments (see Section 2.3). Noteworthy, water had to be autoclaved before the sporulation experiments to exclude the activity of aquatic microbial communities as a factor that could influence sporulation intensity. Since autoclaving was expected to change the water composition compared to the original sample at the sampling site (e.g., phosphates may form insoluble salts with bivalent metals and precipitate, $\mathrm{CO}_{2}$ may be lost due to heating, etc.), all physico-chemical analyses of the water were performed after autoclaving. 


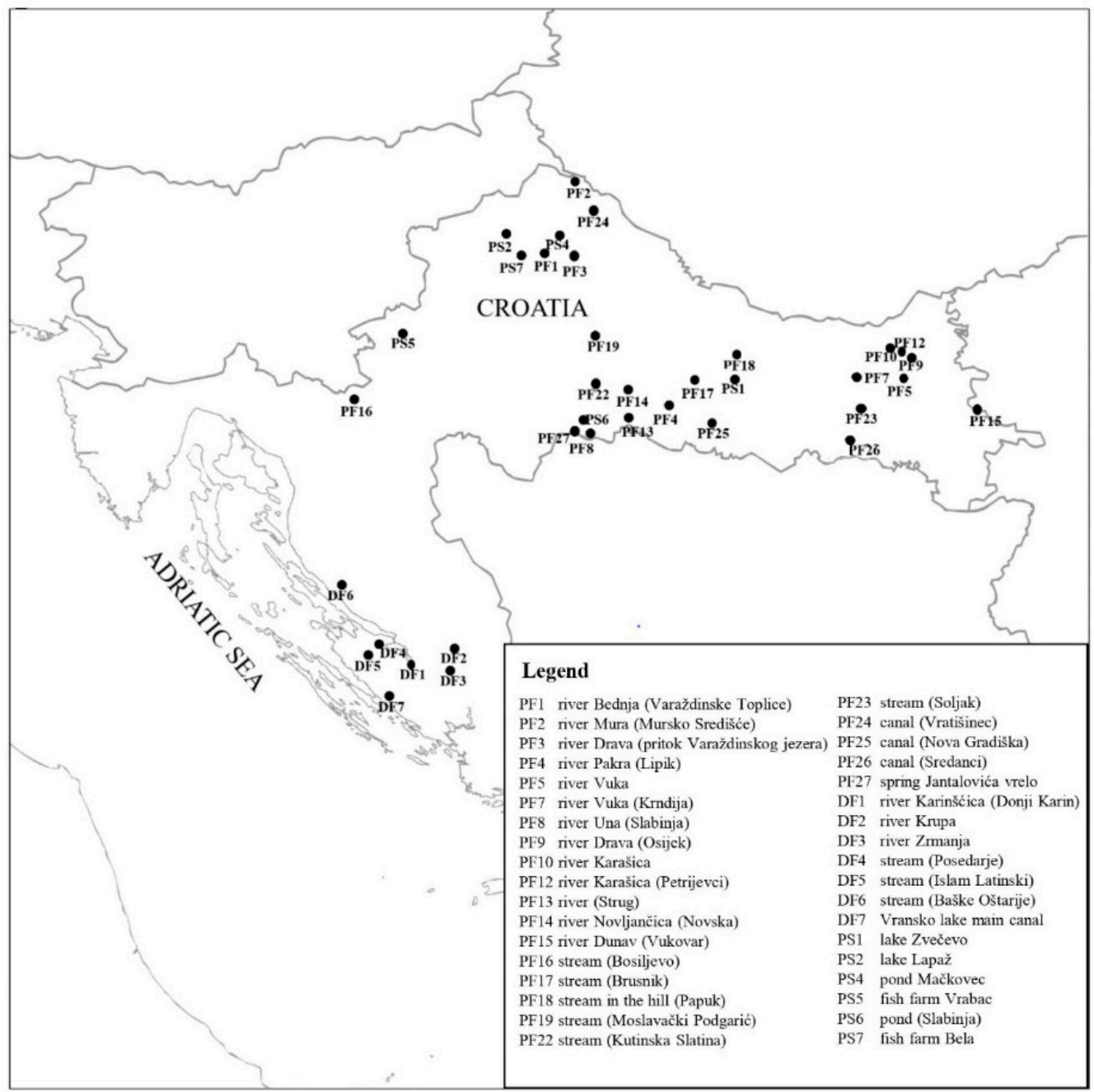

Figure 1. Locations of water sampling $(n=36)$ in Croatia. P-Pannonian ecoregion, D-Dinaric ecoregion, F-flowing, S-stagnant.

\subsection{Physico-Chemical Analyses of Water}

Physico-chemical parameters of the autoclaved water samples, i.e., spectral absorption coefficient (SAC), dissolved organic carbon (DOC), $\mathrm{pH}$, electrical conductivity (EC), ammonium nitrogen $\left(\mathrm{NH}_{4}-\mathrm{N}\right)$, nitrate nitrogen $\left(\mathrm{NO}_{3}-\mathrm{N}\right), \mathrm{SO}_{4}{ }^{2-}, \mathrm{F}^{-}, \mathrm{Cl}^{-}, \mathrm{Mg}^{2+}, \mathrm{Ca}^{2+}, \mathrm{Br}^{-}$, total nitrogen (TN) and total phosphorus (TP), are listed in Table S2. Electrical conductivity and $\mathrm{pH}$ were measured using a $\mathrm{pH} / \mathrm{Cond}-$ meter inoLab 720 instrument (WTW, Xylem Analytics, Weilheim, Germany). The concentration of TP in water samples was determined according to ISO 6878_2004 (DIN EN 6878/D11), while TN was determined according to EN ISO 11905-1. Ammonium nitrogen $\left(\mathrm{NH}_{4}-\mathrm{N}\right)$ was determined according to ISO 7150-1 (DIN 38406 E5-1, UNI 11669:2017). SAC was measured at $254 \mathrm{~nm}$ using a DR 6000 Spectrophotometer (Hach, Düsseldorf, Germany) according to DIN 38404 Part 3 (C3). DOC was determined using TOC-LCPH FA E200 (Shimadzu, Kyoto, Japan). Dissolved anions (fluorides, chlorides, nitrates, sulfates) and cations (calcium, magnesium) were determined according to HRN EN ISO 10304-1: 2009/cor.1:2012 and HRN EN ISO 14911:2001 on the ion chromatograph DIONEX DX-500 with a conductometric detector (CD20) in combination with electrochemical suppressor. An anion column Dionex IonPac AS9-HC and a cation column Dionex IonPac CS12A were used. In addition, $9 \mathrm{mmol} / \mathrm{L} \mathrm{Na}_{2} \mathrm{CO}_{3}$ was used to elute the anions and $20 \mathrm{mmol} / \mathrm{L}$ methanesulfonic acid was used to elute the cations. The eluent flow rate through the column was $1 \mathrm{~mL} / \mathrm{min}$. 


\subsection{Sporulation}

For the in vitro sporulation experiments, we used Aphanomyces astaci isolate PEC 8 (haplogroup B), provided by F. Grandjean (University of Poitiers, Poitiers, France), and Saprolegnia parasitica isolate A1, collected from the surface of eggs of rainbow trout Oncorhynchus mykiss (Walbaum, 1792) [21]. Both isolates were cultured and maintained in the laboratory at $18{ }^{\circ} \mathrm{C}$ on the appropriate solid growth media: peptone-glucose (PG1) medium [43] for A. astaci, and glucose-yeast (GY) medium [44] for S. parasitica.

To test for the differences in sporulation efficiency after washing the mycelia with different samples of natural waters, previously described sporulation protocols were used [32,37], with some modifications. Namely, uniform pieces of agar $\left(4 \mathrm{~mm}^{2}\right)$ containing the fresh mycelial tips of pure cultures were cut and placed into wells of 12-well plates filled with $3 \mathrm{~mL}$ of liquid PG1 medium for $A$. astaci or liquid GY medium for $S$. parasitica. Cultures were incubated at $18{ }^{\circ} \mathrm{C}$ for four days for $A$. astaci and two days for S. parasitica. In the case of $A$. astaci, after three days of incubation the agar plug was removed, and grown hyphae were placed back in the same well filled with liquid PG1 medium and then left to grow for one more day. After incubation of both pathogens, the liquid medium was removed, and hyphal biomass was washed three times with $2 \mathrm{~mL}$ of autoclaved natural water samples using sterile Pasteur pipette and then left in $4 \mathrm{~mL}$ of the same autoclaved water for $24 \mathrm{~h}$ at $18^{\circ} \mathrm{C}$. Then, the mycelia were removed, and the produced motile zoospores were counted in the Thoma chamber using a light microscope LCD MICRO 5MP (Bresser, Rhede, Germany). Three biological replicates (i.e., mycelial inoculums originating from three independently grown cultures) were made for each water sample (i.e., location) and oomycete species, and the number of zoospores of each replicate was counted three times. The average number of zoospores/mL for each location is given in Table S2.

To test whether the addition of humic acid (HA), as an ubiquitous substance that contributes to both SAC and DOC, can induce sporulation of A. astaci and S. parasitica, a range of environmentally relevant HA concentrations were added to the water samples. Two types of water were selected for this experiment: artificial water (AW, ISO 7346-1 and 7346-2, ISO 1996) and one of the natural water samples from our dataset (PF4, Table S2). Artificial water (AW) was prepared by adding salts to Milli-Q water according to ISO 7346-1 and 7346-2 (ISO 1996), i.e., $294.0 \mathrm{mg} / \mathrm{L} \mathrm{CaCl}_{2} \times 2 \mathrm{H}_{2} \mathrm{O}, 123.3 \mathrm{mg} / \mathrm{L} \mathrm{MgSO}_{4} \times 2 \mathrm{H}_{2} \mathrm{O}, 63.0 \mathrm{mg} / \mathrm{L} \mathrm{NaHCO}_{3}$ and $5.5 \mathrm{mg} / \mathrm{L} \mathrm{KCl}$, and autoclaved. HA stock solution $(160 \mathrm{mg} / \mathrm{L}$ in $0.1 \mathrm{M} \mathrm{NaOH}, \mathrm{DOC}=48.0$ $\mathrm{mg} / \mathrm{L}, \mathrm{SAC}=379.9 \mathrm{~m}^{-1}$ ) was filtered through a syringe polyester filter (pore size $=0.45 \mu \mathrm{m}$, $\mathrm{d}=25 \mathrm{~mm}, \mathrm{CHROMAFIL}^{\circledR}$ Xtra PET-45/25, Macherey-Nagel, Düren, Germany). Water samples with different concentrations of HA, i.e., 4,8 and $16 \mathrm{mg} / \mathrm{L}$, were prepared by adding $10 \mathrm{~mL}$ of $\mathrm{HA}$ stock solution, or stock solution diluted with $0.1 \mathrm{M} \mathrm{NaOH}$, to $90 \mathrm{~mL}$ of AW or PF4. Since the addition of $\mathrm{HA}$, dissolved in $0.1 \mathrm{M} \mathrm{NaOH}$, to the water increased the $\mathrm{pH}$, the samples were titrated with $6 \mathrm{M} \mathrm{HCl}$ to reduce the $\mathrm{pH}$ to the initial values. Two negative controls were used, one with the addition of $0.1 \mathrm{NaOH}$ instead of HA (solvent control) and another with the addition of Milli-Q water. In vitro sporulation efficiency was then determined after washing A. astaci and S. parasitica mycelia with HA-supplemented water samples using the 12-well plate protocol described above. Three biological replicates were performed for each oomycete species, water sample and HA concentration.

\subsection{Data Analysis}

To analyze the effects of different physico-chemical properties of water samples (explanatory variables or predictors, $\mathrm{X}$ : $\mathrm{SAC}, \mathrm{DOC}, \mathrm{pH}, \mathrm{EC}, \mathrm{NH}_{4}-\mathrm{N}, \mathrm{NO}_{3}-\mathrm{N}, \mathrm{SO}_{4}{ }^{2-}, \mathrm{F}^{-}, \mathrm{Cl}^{-}$, $\mathrm{Mg}^{2+}, \mathrm{Ca}^{2+}, \mathrm{Br}^{-}, \mathrm{TN}, \mathrm{TP}$ ) on A. astaci and S. parasitica sporulation efficiency (response variables, Y), Partial Least Squares Regression (PLS-R) analysis was performed using the XLSTAT version 2021.3.1.1189 software provided by Microsoft Excel by Addinsoft.

The non-parametric Mann-Whitney U-test was used to determine the significance of differences in sporulation efficiency between HA-supplemented AW and PF4 water samples. The Kruskal-Wallis test, followed by Dunn's post hoc test, was used to estimate the significance of differences in sporulation efficiency between the different concentrations 
of HA and the negative controls. In all cases, the significance level was set at $p<0.05$. The tests were performed in R v. 3.2.0 (R Core Team, 2020).

\section{Results}

Physico-chemical analyses showed an overall good quality of the water samples collected at 36 sites, covering different water types and biogeographical regions in Croatia (Figures 1 and 2, Table S2). However, some parameters in some samples exceeded the thresholds set by national legislation [45], particularly those related to nitrogen content. Nitrate-N and total nitrogen were elevated in 15 out of 36 samples (41\%), ammonium-N in $3 / 36(8 \%), \mathrm{pH}(>9)$ in $2 / 36(6 \%)$ and total phosphorus in $1 / 36(3 \%)$.

We used the collected water samples to wash the mycelia of oomycete pathogens $A$. astaci and $S$. parasitica and induce sporulation. The average sporulation efficiency was similar for both pathogens, i.e., 4444 zoospores $/ \mathrm{mL}$ for $A$. astaci ( $\min =0$, $\max =42,222$ ) and 4537 zoospores $/ \mathrm{mL}$ for $S$. parasitica $(\min =0, \max =37,778)$, but we obtained variable zoospore numbers upon using different water samples, as listed in Table S2.

Using PLS-R multivariate analysis we examined the relationship between the sporulation intensity of $A$. astaci and S. parasitica (response variables, $\mathrm{Y}$ ) and the physico-chemical parameters of water (explanatory variables, $X)$. Quality indices $Q^{2}(\mathrm{cum}), \mathrm{R}^{2} \mathrm{Y}(\mathrm{cum})$ and $\mathrm{R}^{2} \mathrm{X}$ (cum) of the obtained model were $0.09,0.15$ and 0.21 , respectively, for the first component and $-0.03,0.22$ and 0.36 , respectively, for the second component. The PLS-R modelled relationship between blocks of response and explanatory variables is visually presented as a radar of correlation (Figure 3A). In the radar, positively correlated variables are presented close to each other, and those negatively correlated are located far apart, while the strength of the correlation between any two variables is predicted by their respective $r$ values (listed in correlation matrix, Table S3). Based on this, SAC ( $\mathrm{r}=0.476), \mathrm{DOC}(\mathrm{r}=0.375), \mathrm{NH}_{4}-\mathrm{N}$ $(\mathrm{r}=0.356)$ and $\mathrm{F}^{-}(\mathrm{r}=0.353)$ most strongly positively affected $S$. parasitica sporulation, while $A$. astaci sporulation was not significantly affected, neither positively nor negatively, by any of the analyzed water parameters (Figure 3A, Table S3). Moreover, SAC, DOC, F ${ }^{-}$, $\mathrm{NH}_{4}-\mathrm{N}$ and TN also had VIP values $>1$ (Figure 3B), indicating that these parameters are relevant for explaining the sporulation efficiency and contribute significantly to the PLS model $[46,47]$.

Based on the positive effect of SAC and DOC on the sporulation intensity of S. parasitica, we experimentally tested whether the addition of environmentally relevant concentrations of humic acid (HA), a widespread substance that contributes to both SAC and DOC, to water can stimulate sporulation of freshwater oomycete pathogens. The water samples used, artificial water (AW) and one of the natural water samples from our dataset (PF4, Table S2), were selected on the basis that they did not induce sporulation when previously used to wash the oomycete mycelia. AW contains no organic matter (see Materials and Methods), while the SAC and DOC values of PF4 were below average: $3.39 \mathrm{~m}^{-1}$ and $2.73 \mathrm{mg} / \mathrm{L}$, respectively (average SAC in our dataset was $7.09 \mathrm{~m}^{-1}$, while the average DOC was $5.13 \mathrm{mg} / \mathrm{L}$ ). The results obtained were in agreement with the PLS model and showed that the sporulation efficiency of $S$. parasitica increased with increasing concentration of HA (4, 8 and $16 \mathrm{mg} / \mathrm{L}$ ) for both AW and PF4 (Figure 4). In contrast, the addition of HA to the water had no effect on the sporulation of $A$. astaci, i.e., sporulation failed when washing the mycelia with both control samples and HA-supplemented water (data not shown). The sporulation efficiency of $S$. parasitica was significantly higher after washing the mycelium with PF4 than after washing with AW (Mann-Whitney U-test; W = 639.5; $p=0.004)$, probably due to baseline presence of organic matter in the natural water sample. In addition, the sporulation efficiency of S. parasitica was significantly higher in HAsupplemented water than in the negative controls, for both AW and PF4 (Kruskal-Wallis test; $p<0.001$ ) (Figure 4). 

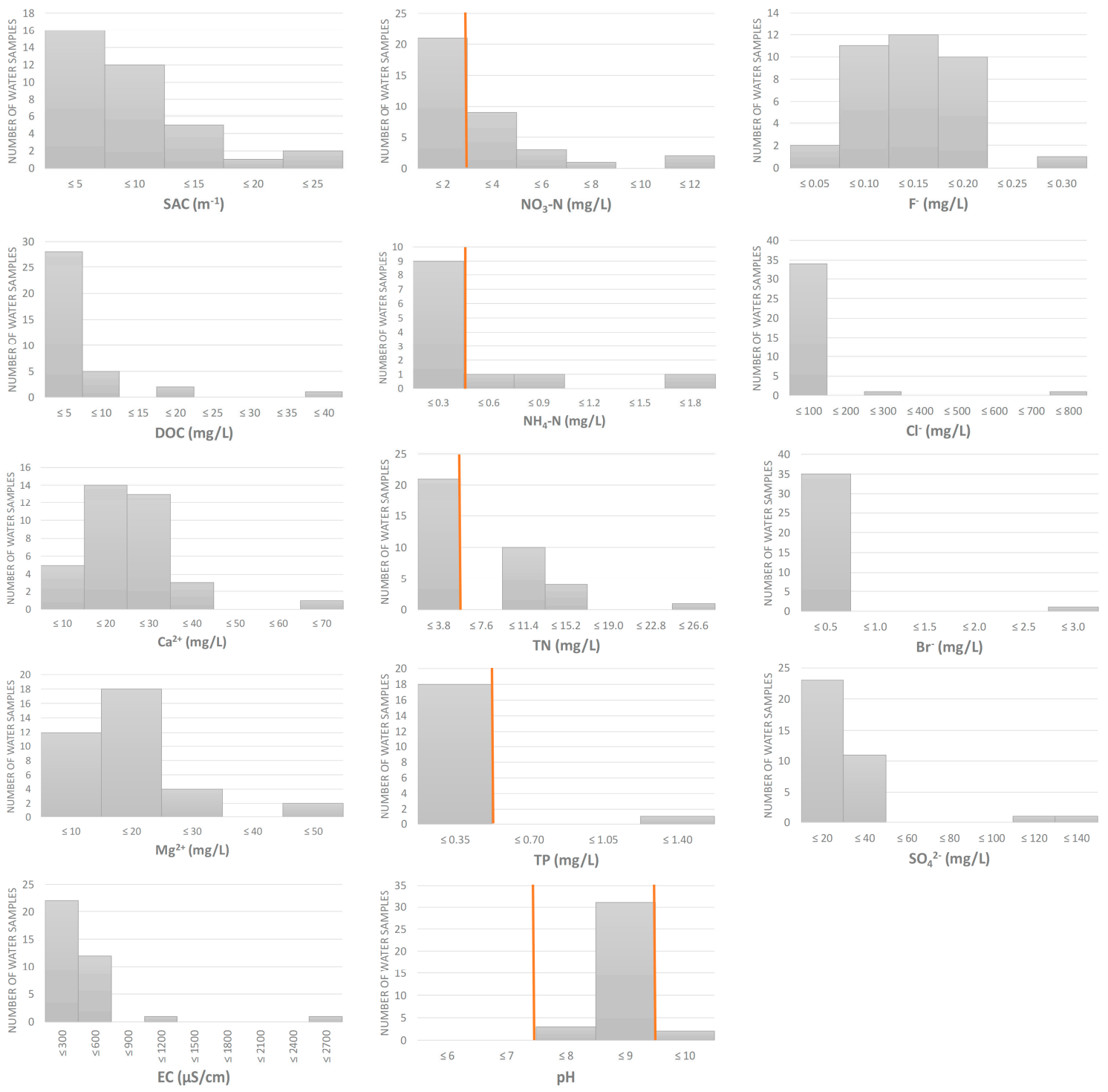

$\mathrm{SO}_{4}{ }^{2-}(\mathrm{mg} / \mathrm{L})$

Figure 2. Physico-chemical properties of water samples $(n=36)$. Orange lines represent the thresholds set by national legislation, available for some of the measured parameters [45], i.e., the upper threshold for $\mathrm{NO}_{3}-\mathrm{N}, \mathrm{NH}_{4}-\mathrm{N}$, TN and TP, and lower and upper thresholds for $\mathrm{pH}$. SAC = spectral absorption coefficient, $\mathrm{DOC}=$ dissolved organic carbon, $\mathrm{EC}=$ electrical conductivity, $\mathrm{TN}=$ total nitrogen, $\mathrm{TP}=$ total phosphorus.

A)

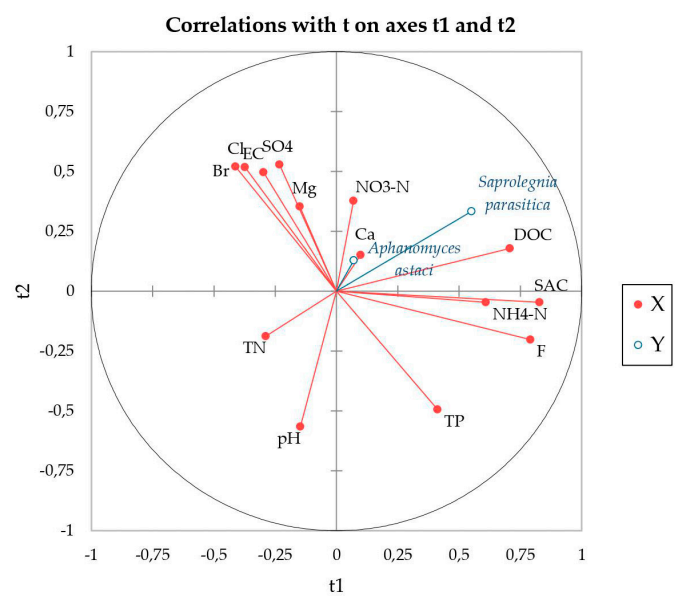

Figure 3. Cont. 


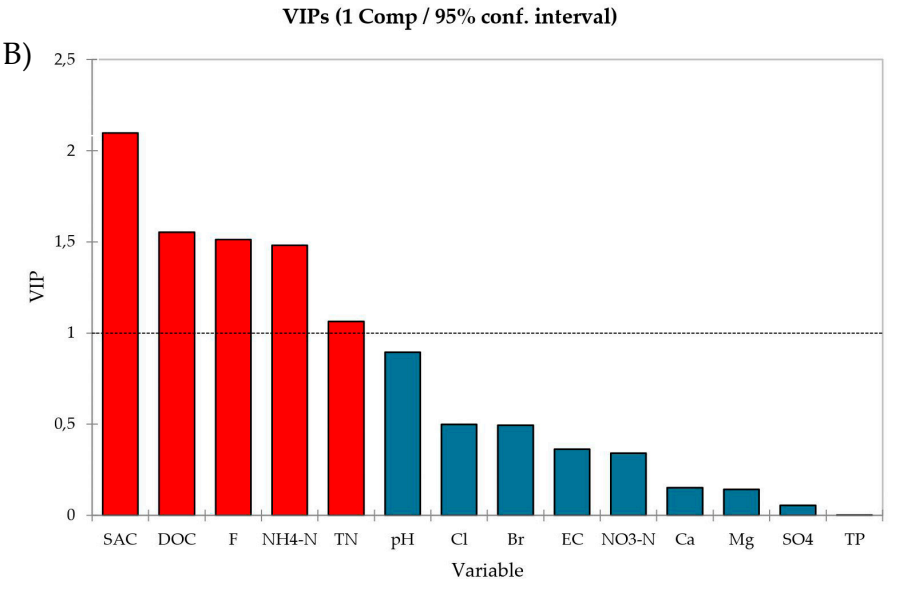

Figure 3. (A) Radar of correlation describing the relationship between the sporulation intensity of $A$. astaci and S. parasitica (response variable, Y, blue lines) and physico-chemical parameters of water (explanatory variables, $\mathrm{X}$, red lines). The percentages of the variances in $\mathrm{X}$ and $\mathrm{Y}$ explained by each variable are indicated on the respective axes. (B) The Variable Importance in the Projection (VIPs) for explanatory variables of the first component (t1). VIPs $>1$ indicate the explanatory variables that contribute the most to the PLS model.
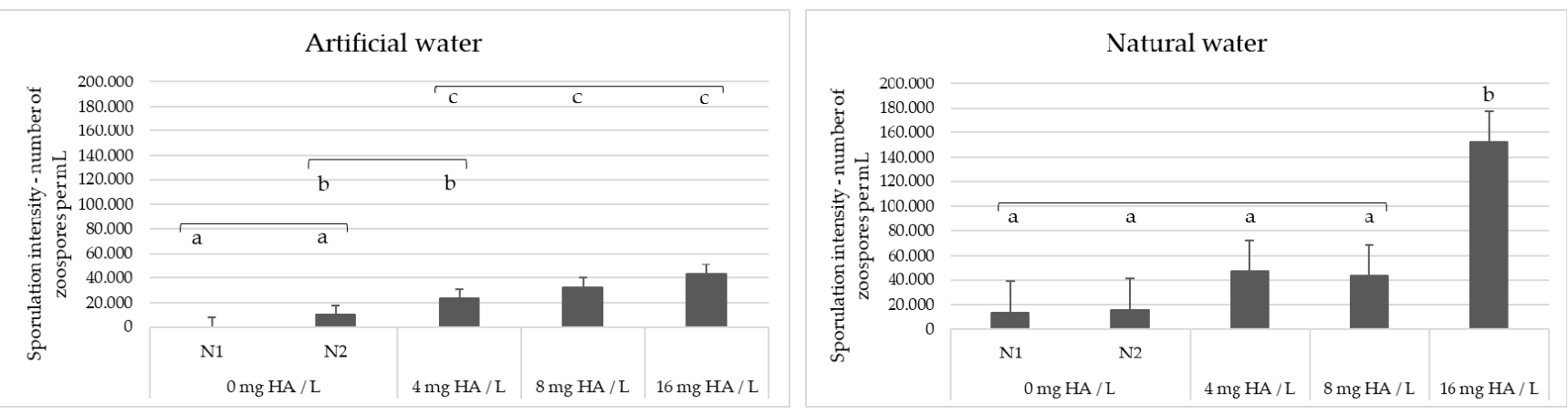

Figure 4. Saprolegnia parasitica sporulation intensity after washing the mycelium with artificial water (AW) or natural water (PF4) supplemented with increasing concentrations of humic acid (HA). In control experiments $\mathrm{N} 1$ and $\mathrm{N} 2$, water and $0.1 \mathrm{M} \mathrm{NaOH}$ were mixed with water samples instead of HA solution in $0.1 \mathrm{NaOH}$, respectively. Bars marked with the same letter $(\mathrm{a}, \mathrm{b}$ or $\mathrm{c}$ ) within each panel are not statistically different from one another.

\section{Discussion}

We present for the first time the differences in sporulation intensity of the freshwater oomycete pathogens $A$. astaci and $S$. parasitica in natural water samples with different physicochemical properties and show that the addition of humic acid, a widespread substance contributing to SAC and DOC levels in freshwater, can trigger sporulation of $S$. parasitica. These results are important both in terms of extending the knowledge on the ecological requirements of these pathogens and as a starting point for the optimization of laboratory protocols for the induction of sporulation.

The parameters related to organic matter in water, especially its aromatic part, were the most important factors positively affecting the sporulation intensity of S. parasitica. In contrast, sporulation of $A$. astaci was not significantly affected by any of the water quality parameters studied. Moreover, the sporulation intensity of $A$. astaci and S. parasitica was not correlated. These results are consistent with the contrasting life strategies of these two pathogens. Aphanomyces astaci is a specialized animal parasite with a narrow host range, whereas $S$. parasitica has a much wider host range and is usually considered an opportunistic secondary pathogen that alternates between a saprophytic and pathogenic 
lifestyle $[4,48]$, although some $S$. parasitica strains have been reported to be highly virulent and cause primary infections [16,49-52]. It has already been shown that the survival of $A$. astaci depends mainly on the presence of host crayfish species [6,23], while our unpublished results on the monitoring of S. parasitica in freshwater systems have shown that its load is correlated with some parameters of water composition, such as electrical conductivity and calcium. We hypothesize that host-specific factors might favor sporulation of $A$. astaci, while in the case of $S$. parasitica, water composition may be more important, but further studies are needed to clarify these possible differences.

The PLS-R results showed that the sporulation intensity of S. parasitica was positively correlated with the SAC and DOC content of the water samples in our dataset. The DOC levels in freshwater environments vary widely from 0.1 to hundreds of $\mathrm{mg} / \mathrm{L}$, but their average values were reported to be about $5 \mathrm{mg} / \mathrm{L}[53,54]$, similar to the values measured in our dataset. Absorbance at $254 \mathrm{~nm}$ (SAC) usually refers to the presence of organic compounds in water, especially those containing aromatic rings or unsaturated carbon bonds (double or triple) in their molecular structure. Thus, the PLS-R results indicate that the presence of aromatic organic matter in water, such as humic acids, can promote sporulation of S. parasitica. This was confirmed experimentally, as washing S. parasitica mycelia with a series of HA-supplemented water samples stimulated sporulation compared to negative controls. In contrast, the addition of HA had no effect on the sporulation of $A$. astaci. Interestingly, humic substances were previously shown to inhibit mycelial growth of $S$. parasitica and a number of related oomycetes from the order Saprolegniales (genera Saprolegnia, Achlya, Leptolegnia, Pythium), but without concomitant inhibition of sporangia development $[55,56]$. This is consistent with our results and suggests that in the presence of humic substances, mycelial growth is impaired and oomycetes therefore switch to the production of sporangia and motile zoospores that can spread to new, more favorable environments.

Furthermore, the PLS-R modelling results suggest that increased fluoride and ammonium concentration could also act as a sporulation trigger, at least for S. parasitica. The range of fluoride concentrations in freshwater is between 0.01 and $0.3 \mathrm{mg} / \mathrm{L}$ [57], which is in accordance with the average fluoride concentration of $0.1 \mathrm{mg} / \mathrm{L}$ in our dataset. The induction of sporulation by environmentally relevant fluoride concentrations could be explained as a response to unfavorable environmental conditions, as in the case of the humic substances mentioned above. High fluoride concentrations have been shown to have negative effects on microbial physiology [58-61], but there are no data yet on the toxicity of fluoride to oomycetes. Furthermore, in some of our samples, ammonium-N concentrations were above the threshold of $0.3 \mathrm{mg} / \mathrm{L}$ set by national legislation [45]. Environmentally relevant ammonium concentrations $(0.05$ and $0.5 \mathrm{mg} / \mathrm{L})$ were related to an increased susceptibility of rainbow trout (Oncorhynchus mykiss) to saprolegniosis [62,63]. This was explained by the host stress response and specific impairments of the defense mechanisms against saprolegniosis, but, considering our results, might also partly be due to the ammonium-induced sporulation increase and thereby the increased virulence of the pathogen. However, it was shown that in the presence of high ammonium-N concentrations ( 8 and $16 \mathrm{mg} / \mathrm{L}$, not found in our dataset) the relative abundance of oomycetes in freshwater habitat can decrease [64]. Similarly, our analysis of S. parasitica load in water samples by droplet digital PCR (ddPCR) showed a negative correlation with ammonium and fluoride concentration (unpublished results). Additional experiments, using a series of increasing ammonium concentrations in the water, should be performed to determine the ammonium concentration range that promotes sporulation, and to compare the effects of ammonium towards mycelium and zoospores of pathogenic oomycetes.

Altogether, our results suggest that some substances might suppress the mycelial growth of the pathogen in a certain range of environmentally relevant concentrations and at the same time promote sporulation, thus facilitating the spread of the pathogens into more favorable environment. Thus, the effects of these compounds, such as ammonium and fluoride, on the sporulation intensity and virulence of freshwater oomycete pathogens 
should be tested, as it was tested here with HA. Furthermore, one of the limitations of this study is that we used only a single isolate from each species. This is unlikely to be representative at the species level, as significant within-species differences in mycelial growth rate, sporulation temperature, zoospore motility, and other parameters were observed for both A. astaci [65] and S. parasitica [66-68]. Therefore, a wider range of isolates/genotypes should be included in in vitro sporulation intensity tests in the future.

The knowledge obtained would enable, from an ecological standpoint, the prediction of the water conditions that might promote the pathogen spreading in natural environments and aquaculture facilities, and thereby aid in the development of preventive measures. On the other hand, the research community working on pathogens from the order Saprolegniales would greatly benefit if the composition of water used for sporulation would be standardized. A range of artificial water samples, with defined composition, could be designed and tested to provide optimal and reproducible oomycete sporulation in laboratory conditions.

Supplementary Materials: The following are available at https://www.mdpi.com/article/10.339 0/microorganisms10030520/s1, Table S1: Water samples collected at different locations in Croatia; Table S2: Physico-chemical parameters of the collected water samples and the average number of zoospores obtained; Table S3: Correlation matrix describing the relationship between sporulation efficiency of $A$. astaci and S. parasitica (response variable) and physico-chemical parameters of water (explanatory variables).

Author Contributions: Conceptualization, A.B.; methodology, D.P., J.Ć. and A.B.; formal analysis, D.G.; investigation, D.P., M.G., T.V., L.Š. and A.M.; resources, A.B.; writing-original draft preparation, D.P.; writing-review and editing, A.B.; visualization, D.P., D.G. and A.B.; supervision, A.B.; project administration, D.G. and A.B.; funding acquisition, A.B. All authors have read and agreed to the published version of the manuscript.

Funding: This research was funded by the Croatian Science Foundation project "Interactions of freshwater pathogenic oomycetes and the environment" (InteractOomyc), grant number UIP-2017-05-6267.

Institutional Review Board Statement: Not applicable.

Informed Consent Statement: Not applicable.

Data Availability Statement: The data presented in this study are available in Tables S1 and S2.

Acknowledgments: The authors are thankful to Mia Schwerer for assistance during the sporulation experiments and to Lucija Surać for the analyses of water.

Conflicts of Interest: The authors declare no conflict of interest.

\section{References}

1. Derevnina, L.; Petre, B.; Kellner, R.; Dagdas, Y.F.; Sarowar, M.N.; Giannakopoulou, A.; de la Concepcion, J.C.; Chaparro-Garcia, A.; Pennington, H.G.; van West, P.; et al. Emerging oomycete threats to plants and animals. Philos. Trans. R. Soc. B Biol. Sci. 2016, 371, 20150459. [CrossRef] [PubMed]

2. Fisher, M.C.; Henk, D.A.; Briggs, C.J.; Brownstein, J.S.; Madoff, L.C.; McCraw, S.L.; Gurr, S.J. Emerging fungal threats to animal, plant and ecosystem health. Nature 2012, 484, 186-194. [CrossRef] [PubMed]

3. Gozlan, R.E.; Marshall, W.; Lilje, O.; Jessop, C.; Gleason, F.H.; Andreou, D. Current ecological understanding of fungal-like pathogens of fish: What lies beneath? Front. Microbiol. 2014, 5, 1-16. [CrossRef] [PubMed]

4. van den Berg, A.H.; McLaggan, D.; Diéguez-Uribeondo, J.; van West, P. The impact of the water moulds Saprolegnia diclina and Saprolegnia parasitica on natural ecosystems and the aquaculture industry. Fungal Biol. Rev. 2013, 27, 33-42. [CrossRef]

5. Diéguez-Uribeondo, J.; Cerenius, L.; Dyková, I.; Gelder, S.; Henttonen, P.; Jiravanichpaisal, P.; Lom, J.; Söderhäll, K. Pathogens, parasites and ectocommensals. In Atlas of Crayfish in European; Souty-Grosset, C., Holdich, D.M., Noël, P.Y., Reynolds, J.D., Haffner, P., Eds.; Muséum National d'Histoire Naturelle: Paris, France, 2006; pp. 131-150.

6. Söderhäll, K.; Cerenius, L. The crayfish plague fungus: History and recent advances. Freshw. Crayfish 1999, 12, 11-35.

7. van West, P. Saprolegnia parasitica, an oomycete pathogen with a fishy appetite: New challenges for an old problem. Mycologist 2006, 20, 99-104. [CrossRef]

8. Holdich, D.M.; Reynolds, J.D.; Souty-Grosset, C.; Sibley, P.J. A review of the ever increasing threat to European crayfish from non-indigenous crayfish species. Knowl. Manag. Aquat. Ecosyst. 2009, 11, 1-46. [CrossRef] 
9. Martín-Torrijos, L.; Kawai, T.; Makkonen, J.; Jussila, J.; Kokko, H.; Diéguez-Uribeondo, J. Crayfish plague in Japan: A real threat to the endemic Cambaroides japonicus. PLoS ONE 2018, 1903, e0195353. [CrossRef]

10. Peiró, D.F.; Almerão, M.P.; Delaunay, C.; Jussila, J.; Makkonen, J.; Bouchon, D.; Araujo, P.B.; Souty-Grosset, C. First detection of the crayfish plague pathogen Aphanomyces astaci in South America: A high potential risk to native crayfish. Hydrobiologia 2016, 781, 181-190. [CrossRef]

11. Putra, M.D.; Bláha, M.; Wardiatno, Y.; Krisanti, M.; Jerikho, R.; Kamal, M.M.; Mojžišová, M.; Bystřický, P.K.; Kouba, A.; Kalous, L.; et al. Procambarus clarkii (Girard, 1852) and crayfish plague as new threats for biodiversity in Indonesia. Aquat. Conserv. Mar. Freshw. Ecosyst. 2018, 28, 1434-1440. [CrossRef]

12. Martín-Torrijos, L.; Jose Correa-Villalona, A.; Juan Carlos Azofeifa-Solano, J.C.; Villalobos-Rojas, F.; Wehrtmann, I.S.; DiéguezUribeondo, J. First detection of the crayfish plague pathogen Aphanomyces astaci in Costa Rica: European mistakes should not be repeated. Front. Ecol. Evol. 2021, 9, 376. [CrossRef]

13. Alderman, D.J. Geographical spread of bacterial and fungal diseases of crustaceans. Rev. Sci. Tech. Int. Epizoot. 1996, 15, 603-632. [CrossRef] [PubMed]

14. Cerenius, L.; Bangyeekhun, E.; Keyser, P.; Söderhäll, I.; Söderhäll, K. Host prophenoloxidase expression in freshwater crayfish is linked to increased resistance to the crayfish plague fungus, Aphanomyces astaci. Cell. Microbiol. 2003, 5, 353-357. [CrossRef] [PubMed]

15. Cao, H.; Zheng, W.; Xu, J.; Ou, R.; He, S.; Yang, X. Identification of an isolate of Saprolegnia ferax as the causal agent of saprolegniosis of Yellow catfish (Pelteobagrus fulvidraco) eggs. Vet. Res. Commun. 2012, 36, 239-244. [CrossRef] [PubMed]

16. Thoen, E.; Evensen, Ø.; Skaar, I. Pathogenicity of Saprolegnia spp. to Atlantic salmon, Salmo salar L., eggs. J. Fish Dis. 2011, 34, 601-608. [CrossRef]

17. Rezinciuc, S.; Sandoval-Sierra, J.V.; Diéguez-Uribeondo, J. Molecular identification of a bronopol tolerant strain of Saprolegnia australis causing egg and fry mortality in farmed brown trout, Salmo trutta. Fungal Biol. 2014, 118, 591-600. [CrossRef]

18. Hatai, K.; Hoshiai, G. Mass mortality in cultured coho salmon (Oncorhynchus kisutch) due to Saprolegnia parasitica Coker. J. Wildl. Dis. 1992, 28, 532-536. [CrossRef]

19. Bruno, D.; West, V.P.; Beakes, G. Saprolegnia and other oomycetes. In Fish Diseases and Disorders: Viral, Bacterial and Fungal Infections Volume 3; Woo, P.T.K., Bruno, D.W., Eds.; CABI International: Wallingford, UK, 2011; Volume 3, pp. 669-720.

20. Ravasi, D.; De Respinis, S.; Wahli, T. Multilocus sequence typing reveals clonality in Saprolegnia parasitica outbreaks. J. Fish Dis. 2018, 41, 1653-1665. [CrossRef]

21. Pavić, D.; Grbin, D.; Šver, L.; Vladušić, T.; Galuppi, R.; Tedesco, P.; Bielen, A. Identification and molecular characterization of oomycete isolates from trout farms in Croatia, and their upstream and downstream water environments. Aquaculture 2021, 540, 736652. [CrossRef]

22. Tedesco, P.; Saraiva, M.; Sandoval-Sierra, J.V.; Fioravanti, M.L.; Morandi, B.; Dieguez-Uribeondo, J.; Van West, P.; Galuppi, R. Evaluation of potential transfer of the pathogen Saprolegnia parasitica between farmed salmonids and wild fish. Pathogens 2021, 10, 926. [CrossRef]

23. Diéguez-Uribeondo, J.; García, M.A.; Cerenius, L.; Kozubíková, E.; Ballesteros, I.; Windels, C.; Weiland, J.; Kator, H.; Söderhäll, K.; Martín, M.P. Phylogenetic relationships among plant and animal parasites, and saprotrophs in Aphanomyces (Oomycetes). Fungal Genet. Biol. 2009, 46, 365-376. [CrossRef] [PubMed]

24. Phillips, A.J.; Anderson, V.L.; Robertson, E.J.; Secombes, C.J.; van West, P. New insights into animal pathogenic oomycetes. Trends Microbiol. 2008, 16, 13-19. [CrossRef] [PubMed]

25. Oidtmann, B.; Heitz, E.; Rogers, D.; Hoffmann, R.W. Transmission of crayfish plague. Dis. Aquat. Organ. 2002, 52, 159-167. [CrossRef] [PubMed]

26. Unestam, T. On the adaptation of Aphanomyces astaci as a parasite. Physiol. Plant. 1969, 22, 221-235. [CrossRef]

27. Cerenius, L.; Söderhäll, K. Chemotaxis in Aphanomyces astaci, an arthropod-parasitic fungus. J. Invertebr. Pathol. 1984, 43, 278-281. [CrossRef]

28. Cerenius, L.; Söderhäll, K.; Persson, M.; Ajaxon, R. The crayfish plague fungus Aphanomyces astaci-Diagnosis, isolation and pathobiology. Freshw. Crayfish 1988, 7, 131-144.

29. Willoughby, L.G. Fungi and Fish Diseases; Pisces Press: Stirling, UK, 1994

30. Hatai, K.; Hoshiai, G. Pathogenicity of Saprolegnia parasitica Coker. In Salmon Saprolegniasis; Mueller, G.J., Ed.; U.S. Department of Energy, Bonneville Power Administration: Portland, OR, USA, 1994; pp. 87-98.

31. Cerenius, L.; Söderhäll, K. Repeated zoospore emergence from isolated spore cysts of Aphanomyces astaci. Exp. Mycol. 1984, 8, 370-377. [CrossRef]

32. Diéguez-Uribeondo, J.; Cerenius, L.; Söderhäll, K. Repeated zoospore emergence in Saprolegnia parasitica. Mycol. Res. 1994, 98, 810-815. [CrossRef]

33. Walker, C.A.; van West, P. Zoospore development in the oomycetes. Fungal Biol. Rev. 2007, 21, 10-18. [CrossRef]

34. Pavić, D.; Bielen, A.; Hudina, S.; Špoljarić, I.; Grandjean, F.; Jussila, J.; Maguire, I. Distribution of Aphanomyces astaci Schikora, 1906 , the causative agent of crayfish plague, in the Plitvice Lakes National Park, Croatia. BioInvasions Rec. 2021, 10, 654-668. [CrossRef]

35. Bly, J.E.; Lawson, L.A.; Dale, D.J.; Szalai, A.J.; Durburow, R.M.; Clem, L.W. Winter saprolegniosis in channel catfish. Dis. Aquat. Organ. 1992, 13, 155-164. [CrossRef]

36. Unestam, T. On the physiology of zoospore production in Aphanomyces astaci. Physiol. Plant. 1969, 22, 236-246. [CrossRef] 
37. Makkonen, J.; Jussila, J.; Kortet, R.; Vainikka, A.; Kokko, H. Differing virulence of Aphanomyces astaci isolates and elevated resistance of noble crayfish Astacus astacus against crayfish plague. Dis. Aquat. Organ. 2012, 102, 129-136. [CrossRef]

38. Heungens, K.; Parke, J.L. Zoospore homing and infection events: Effects of the biocontrol bacterium Burkholderia cepacia AMMDR1 on two Oomycete pathogens of pea (Pisum sativum L.). Appl. Environ. Microbiol. 2000, 66, 5192-5200. [CrossRef] [PubMed]

39. Appiah, A.A.; Van West, P.; Osborne, M.C.; Gow, N.A.R. Potassium homeostasis influences the locomotion and encystment of zoospores of plant pathogenic oomycetes. Fungal Genet. Biol. 2005, 42, 213-223. [CrossRef]

40. Rantamäki, J.; Cerenius, L.; Söderhäll, K. Prevention of transmission of the crayfish plague fungus (Aphanomyces astaci) to the freshwater crayfish Astacus astacus by treatment with $\mathrm{MgCl}_{2}$. Aquaculture 1992, 104, 11-18. [CrossRef]

41. Weyhenmeyer, G.A.; Hartmann, J.; Hessen, D.O.; Kopáček, J.; Hejzlar, J.; Jacquet, S.; Hamilton, S.K.; Verburg, P.; Leach, T.H.; Schmid, M.; et al. Widespread diminishing anthropogenic effects on calcium in freshwaters. Sci. Rep. 2019, 9, 1-10. [CrossRef]

42. Preuett, J.A.; Collins, D.J.; Luster, D.G.; Widmer, T.L. The effect of salinity on the survival, growth, sporulation and infection of Phytophthora ramorum. Fungal Ecol. 2016, 23, 123-130. [CrossRef]

43. Unestam, T. Studies on the crayfish plague fungus Aphanomyces astaci I. Some factors affecting growth in vitro. Physiol. Plant. 1965, 18, 483-506. [CrossRef]

44. Min, H.; Hatai, K.; Bai, S. Some inhibitory effects of chitosan on fish-pathogenic oomycete, Saprolegnia parasitica. Fish Pathol. 1998, 29, 73-77. [CrossRef]

45. Croatian Community (2019) NN 96/19 (Official Gazette 96/19); Status Regulation on the Water Quality. Narodne novine d.d.: Zagreb, Croatia, 9 October 2019.

46. Jain, P.; Vineis, P.; Liquet, B.; Vlaanderen, J.; Bodinier, B.; van Veldhoven, K.; Kogevinas, M.; Athersuch, T.J.; Font-Ribera, L.; Villanueva, C.M.; et al. A multivariate approach to investigate the combined biological effects of multiple exposures. J. Epidemiol. Community Health 2018, 72, 564-571. [CrossRef] [PubMed]

47. Lew, S.; Glińska-Lewczuk, K.; Lew, M. The effects of environmental parameters on the microbial activity in peat-bog lakes. PLoS ONE 2019, 14, e0224441. [CrossRef]

48. De la Bastide, P.Y.; Leung, W.L.; Hintz, W.E. Species composition of the genus Saprolegnia in fin fish aquaculture environments, as determined by nucleotide sequence analysis of the nuclear rDNA ITS regions. Fungal Biol. 2015, 119, 27-43. [CrossRef] [PubMed]

49. Neish, G.A.; Hughes, G.C. Diseases of fish. In Fungal Diseases of Fishes; T.W.F. Publications: Neptune, NJ, USA, $1980 ;$ p. 159.

50. Stueland, S.; Hatai, K.; Skaar, I. Morphological and physiological characteristics of Saprolegnia spp. strains pathogenic to Atlantic salmon, Salmo salar L. J. Fish Dis. 2005, 28, 445-453. [CrossRef] [PubMed]

51. Whisler, H.C. Identification od Saprolegnia spp. Pathogenic in Chinook Salmon; Final Report, DE-AC79-90BP02836; University of Washington: Washington, DC, USA, 1996.

52. Willoughby, L.G.; Pickering, A.D. Viable Saprolegniaceae spores on the epidermis of the salmonid fish Salmo trutta and Salvelinus alpinus. Trans. Br. Mycol. Soc. 1977, 68, 91-95. [CrossRef]

53. Bittar, T.B.; Vieira, A.A.H.; Stubbins, A.; Mopper, K. Competition between photochemical and biological degradation of dissolved organic matter from the cyanobacteria microcystis aeruginosa. Limnol. Oceanogr. 2015, 60, 1172-1194. [CrossRef]

54. Sobek, S.; Tranvik, L.J.; Prairie, Y.T.; Kortelainen, P.; Cole, J.J. Patterns and regulation of dissolved organic carbon: An analysis of 7,500 widely distributed lakes. Limnol. Oceanogr. 2007, 52, 1208-1219. [CrossRef]

55. Meinelt, T.; Paul, A.; My, T.; Zwirnmann, E.; Kr, A.; Wienke, A.; Steinberg, C.E.W. Reduction in vegetative growth of the water mold Saprolegnia parasitica (Coker) by humic substance of different qualities. Aquat. Toxicol. 2007, 83, 93-103. [CrossRef]

56. Masigol, H.; Khodaparast, S.A.; Woodhouse, J.N.; Rojas-Jimenez, K.; Fonvielle, J.; Rezakhani, F.; Mostowfizadeh-Ghalamfarsa, R.; Neubauer, D.; Goldhammer, T.; Grossart, H.P. The contrasting roles of aquatic fungi and oomycetes in the degradation and transformation of polymeric organic matter. Limnol. Oceanogr. 2019, 64, 2662-2678. [CrossRef]

57. Camargo, J.A. Fluoride toxicity to aquatic organisms: A review. Chemosphere 2003, 50, 251-264. [CrossRef]

58. Marquis, R.E.; Clock, S.A.; Mota-Meira, M. Fluoride and organic weak acids as modulators of microbial physiology. FEMS Microbiol. Rev. 2003, 26, 493-510. [CrossRef] [PubMed]

59. Mendes, G.; Zafra, D.L.; Vassilev, N.B.; Silva, I.R.; Ribeiro, J.I.J.; Costa, M.D. Biochar enhances Aspergillus niger rock phosphate solubilization by increasing organic acid production and alleviating fluoride toxicity. Appl. Environ. Microbiol. 2014, 80, 3081-3085. [CrossRef] [PubMed]

60. Montagnolli, R.N.; Lopes, P.R.M.; Cruz, J.M.; Claro, E.M.T.; Quiterio, G.M.; Bidoia, E.D. The effects of fluoride based fire-fighting foams on soil microbiota activity and plant growth during natural attenuation of perfluorinated compounds. Environ. Toxicol. Pharmacol. 2017, 50, 119-127. [CrossRef] [PubMed]

61. Zhang, X.; Gao, X.; Li, C.; Luo, X.; Wang, Y. Fluoride contributes to the shaping of microbial community in high fluoride groundwater in Qiji County, Yuncheng City, China. Sci. Rep. 2019, 9, 1-10. [CrossRef]

62. Carballo, M.; Munoz, M.J.; Cuellar, M.; Tarazona, J.V. Effects of waterborne copper, cyanide, ammonia, and nitrite on stress parameters and changes in susceptibility to saprolegniosis in rainbow trout (Oncorhynchus mykiss). Appl. Environ. Microbiol. 1995, 61, 2108-2112. [CrossRef]

63. Carballo, M.; Munoz, M.J. Effect of sublethal concentrations of four chemicals on susceptibility of juvenile rainbow trout (Oncorhynchus mykiss) to saprolegniosis. Appl. Environ. Microbiol. 1991, 57, 1813-1816. [CrossRef]

64. Yan, L.; Mu, X.; Han, B.; Zhang, S.; Qiu, C.; Ohore, O.E. Ammonium loading disturbed the microbial food webs in biofilms attached to submersed macrophyte Vallisneria natans. Sci. Total Environ. 2019, 659, 691-698. [CrossRef] 
65. Diéguez-Uribeondo, J.; Huang, T.-S.; Cerenius, L.; Söderhäll, K. Physiological adaptation of an Aphanomyces astaci strain isolated from the freshwater crayfish Procambarus clarkii. Mycol. Res. 1995, 99, 574-578. [CrossRef]

66. Diéguez-Uribeondo, J.; Fregeneda-Grandes, J.M.; Cerenius, L.; Pérez-Iniesta, E.; Aller-Gancedo, J.M.; Tellería, M.T.; Söderhäll, K.; Martín, M.P. Re-evaluation of the enigmatic species complex Saprolegnia diclina-Saprolegnia parasitica based on morphological, physiological and molecular data. Fungal Genet. Biol. 2007, 44, 585-601. [CrossRef]

67. Masigol, H.; Khodaparast, S.A.; Mostowfizadeh-Ghalamfarsa, R.; Rojas-Jimenez, K.; Woodhouse, J.N.; Neubauer, D.; Grossart, H.P. Taxonomical and functional diversity of Saprolegniales in Anzali lagoon, Iran. Aquat. Ecol. 2020, 51, 323-336. [CrossRef]

68. Bangyeekhun, E.; Quiniou, S.M.A.; Bly, J.E.; Cerenius, L. Characterisation of Saprolegnia sp. isolates from channel catfish. Dis. Aquat. Organ. 2001, 45, 53-59. [CrossRef] [PubMed] 